\title{
STIMULATION OF REPRODUCTION IN CAPTIVITY OF THE WILD RABBIT, ORYCTOLAGUS CUNICULUS
}

\author{
G. E. ADAMS \\ A.R.C. Unit of Reproductive Physiology and Biochemistry, \\ University of Cambridge*
}

(Received 15th August 1974)

\begin{abstract}
Summary. Female wild rabbits which failed to breed under laboratory conditions were treated with gonadotrophins and artificially inseminated with epididymal spermatozoa. The fertilized eggs so obtained were transferred to synchronous domestic rabbits. Altogether, 185 eggs were transferred to thirty-six recipients. Thirty-three of the recipients maintained pregnancy to term and nearly half of the transferred eggs developed into normal young. Birthweights ranged from 45 to $59 \mathrm{~g}$. Postnatal survival was excellent. Females born in captivity remained sexually immature in spite of attaining normal adult body weights. Sexual development was apparently normal in the males, although most remained shy breeders. Incidental observations on ovarian response, egg size and rate of development are presented.
\end{abstract}

\section{INTRODUGTION}

Assheton (1910) observed that "wild rabbits live and breed quite happily in captivity provided they are allowed sufficient cover", but the actual times of mating could not be recorded due to their shy nature. King Wilson (1936) also obtained litters when wild rabbits were given plenty of space-a room about $3 \mathrm{~m}^{2}$ and containing a hide made of turves. He found that the wild bucks made no attempt to mate with tame does under observation and apparently no matings resulted when they were left together in a hutch for a day or more. Ward (1971), however, obtained twenty-six litters from nine female rabbits, born in captivity from New Zealand wild stock, which were kept caged indoors through one breeding season. Males were introduced periodically to the females which were re-mated immediately after parturition; apparently the matings took place unobserved.

In my own experience, wild does introduced into the laboratory before puberty fail to mature sexually whilst does captured as adults tend to become anoestrous. On the other hand, litters have resulted when wild bucks were caged together with tame does, though mating was only rarely observed. The following is an account of the propagation of wild rabbits by artificial means in the laboratory, carried out between 1968 and 1972.

* Postal address: 307 Huntingdon Road, Cambridge CB3 0JQ. 


\section{MATERIALS AND METHODS}

Animals

The foundation stock consisted of two does and one buck supplied by $\mathrm{Dr}$ Meade-Briggs, Ministry of Agriculture, Fisheries and Food, Worplesdon, Surrey, and two young does, one caught at Lolworth, Cambridgeshire, the other near Thaxted, Essex. All of these animals were agouti coloured. Further stock was produced by the procedures described below. The mean liveweights (in $g, \pm$ S.E.) of sixteen adult females was $1305 \pm 39$ (range 1050 to 1700) and of eight males was $1316 \pm 52$ (range 1200 to 1600 ).

The animals were kept indoors in wooden hutches, the dimensions of which were: floor area $57 \mathrm{~cm} \times 57 \mathrm{~cm}$, height $50 \mathrm{~cm}$. They were allowed free access to Diet 18 (Dixons, Ware) and water. Straw was used as bedding.

\section{Artificial insemination}

It was not possible to collect semen with an artificial vagina and none of the wild bucks would copulate at the required time. Therefore, spermatozoa were obtained from the cauda epididymidis either at autopsy or following the removal of one testis. To recover spermatozoa, $0.5 \mathrm{ml}$ physiological saline was injected by way of the ductus deferens into the cauda epididymidis which was then cut with sharp pointed scissors, whilst being held over a watch-glass into which the flushings were collected. The density of the spermatozoa was estimated using a haemocytometer: the mean number of spermatozoa recovered per epididymis was $68 \cdot 9 \pm 17 \cdot 6 \times 10^{6}$ (range, $23 \times 10^{6}$ to $193 \times 10^{6}$ ). Two techniques of insemination were used. Initially, laparotomy was performed and the spermatozoa were introduced directly into the uterus (two does) or vagina (eleven does) by piercing the wall with a Pasteur pipette and depositing 1 to $2 \times 10^{6}$ spermatozoa in $0.02 \mathrm{ml}$ saline. Secondly, seventeen does were artificially inseminated, using a special pipette to deposit spermatozoa in the vagina, as described by Adams (1962a). The pipette was made from 2-mm bore glass tubing (o.d. $4 \mathrm{~mm}$, length $11.5 \mathrm{~cm}$ ). The depth of insertion into the vagina was 4 to $5 \mathrm{~cm}$. Approximately 10 to $20 \times 10^{6}$ spermatozoa were inseminated in $0.2 \mathrm{ml}$ diluent.

Before insemination, the females were primed with a horse anterior pituitary preparation (HAP), each one receiving six subcutaneous injections (6 $\mathrm{mg}$ total) over 3 days. Ovulation was induced by injecting 25 i.u. HCG (Lutormone: Burroughs Wellcome) intravenously about $1 \mathrm{hr}$ after insemination, which itself took place about $12 \mathrm{hr}$ after the final priming injection.

\section{Egg recovery}

Between 24 and $31 \mathrm{hr}$ or between $55 \frac{1}{2}$ and $61 \mathrm{hr}$ after giving the HCG, egg recovery was performed either in vivo (Adams, 1953) or at autopsy. In either case, $1 \mathrm{ml}$ of $0.9 \% \mathrm{NaCl}$ solution was used as the flushing medium. For recovery in vivo, a small glass cannula was used whose dimensions were: both arms $37 \mathrm{~mm}$ long, internal angle $120^{\circ}$; outer diameter: minimum $1 \mathrm{~mm}$, maximum $2 \mathrm{~mm}$; wall thickness: minimum $40 \mu \mathrm{m}$, maximum $80 \mu \mathrm{m}$. If the fimbria permitted, the wider arm of the cannula was introduced into the oviduct. After recovery, the eggs were examined under a Zeiss zoom microscope $(\times 80)$ and quickly classified according to cell stage. Any uncleaved eggs were examined for the 
presence of two polar bodies and extra spermatozoa. Apart from one group of eggs recovered $55 \frac{1}{2} \mathrm{hr}$ after the injection of HCG, which were cultured overnight before transfer, the remainder were transferred to recipients within $1 \mathrm{hr}$ of recovery. Some of the unfertilized eggs were measured, as described by Adams (1958).

\section{Recipients}

Seventeen crossbred does, weighing about $3.5 \mathrm{~kg}$, and nineteen Dutch belted does $(2 \mathrm{~kg})$, all of which had produced at least one litter, were used as recipients. Ovulation was induced by mating once with a vasectomized male and, in some cases, 25 i.u. HCG was injected intravenously to ensure against ovulation failure.

Eggs recovered from donors 24 to $31 \mathrm{hr}$ after injection of HCG were transferred to each oviduct of thirty-one recipients mated 24 to $30 \mathrm{hr}$ earlier (Group A). Transfer was effected through the fimbriae by means of a pipette connected to a 2-ml syringe. The tip of the pipette, which was fire-polished, was introduced about $3 \mathrm{~cm}$ into the oviduct before the fluid, approximately $0.02 \mathrm{ml}$, containing the eggs was gently expelled. Eggs recovered at the morula stage were transferred to the uterine horns (Adams, 1962b) of five recipients mated $72 \mathrm{hr}$ previously (Group B). The mean numbers of eggs transferred per recipient were $4 \cdot 8 \pm 0.3$ (range, 3 to 8 ) and $7 \cdot 4 \pm 1.6$ (3 to 13) in Groups A and B, respectively. About 10 days after egg transfer, the recipients were palpated in order to determine whether they were pregnant. Near term, inspections were made twice daily for evidence of parturition. The young were weighed when first seen, which was usually well within $12 \mathrm{hr}$ of parturition.

\section{Donors \\ RESULTS}

In twenty-one does treated with HAP between 6 and 12 months of age, the mean number of ovulations (determined from ovulation sites on the ovary and corrected, see below) was $10 \cdot 6 \pm 1 \cdot 3$ (range, 4 to 25 ) and in six others of unknown age it was $8 \cdot 3 \pm 1.8$ ( 3 to 15$)$. Six of nine does which were treated on a second occasion failed to ovulate whilst the remainder responded with only two or three ovulations.

Eggs were recovered from the excised tubes of twenty does and in vivo from ten does. There was generally a close agreement between the counts of ovulations and of eggs recovered. In eight does, however, the latter exceeded the former and adjustment to equivalence was then made. On this basis, the proportion of eggs recovered was $92 \%(145 / 158)$ from the excised tubes and $92 \%(113 / 122)$ in vivo. In forty-one of the fifty-seven oviducts flushed, $100 \%$ of the eggs were recovered.

Fertilized eggs were recovered from all but six of the thirty does that ovulated. Over-all, the fertilization rate was $74.4 \%(192 / 258)$, or $94 \cdot 1 \%(192 / 204)$ if the six does with fertilization failure are excluded. In the thirteen surgically inseminated does, $88.6 \%(70 / 79)$ of the eggs were fertilized, compared with $68.1 \%(122 / 179)$ of those inseminated per vaginam. When only those does with fertilized eggs are considered, however, the proportions of eggs fertilized become $95 \cdot 9 \%(70 / 73)$ and $93.1 \%(122 / 131)$, respectively. 
The majority of the eggs recovered between 24 and $29 \mathrm{hr}$ after the injection of HCG were at the two-cell stage but thereafter, up to $31 \mathrm{hr}$, the four-cell stage predominated. Of the thirty-nine fertilized eggs recovered at 55 to $61 \mathrm{hr}$ after injection of HCG, all, except one which was at the eight-cell stage, were well advanced morulae. The dimensions of forty unfertilized eggs recovered from the oviducts of three does, 26,30 and $61 \mathrm{hr}$ after receiving the ovulating injection, are given in Table 1. The over-all mean diameter of the eggs, excluding the mucin layer, varied from 153 to $162 \mu \mathrm{m}$. Eggs recovered at $61 \mathrm{hr}$ had a particularly well-developed mucin layer.

Table 1. Dimensions of one-cell oviducal eggs in the wild rabbit

\begin{tabular}{|c|c|c|c|c|}
\hline \multirow{2}{*}{$\begin{array}{l}\text { Time between } H C G \\
\text { and egg recovery }(h r)\end{array}$} & \multirow{2}{*}{$\begin{array}{l}\text { No. of } \\
\text { eggs }\end{array}$} & \multicolumn{3}{|c|}{ Diameter $(\mu m)$} \\
\hline & & $\begin{array}{l}\text { Zona } \\
\text { pellucida }\end{array}$ & $\begin{array}{l}\text { Intra-zonal } \\
\text { space }\end{array}$ & $\begin{array}{l}\text { Mucin } \\
\text { layer }\end{array}$ \\
\hline 26 & 13 & $\begin{array}{c}21 \cdot 7 \pm 0 \cdot 6 \\
(18 \cdot 8 \text { to } 24 \cdot 0)\end{array}$ & $\begin{array}{c}140 \cdot 7 \pm 1 \cdot 3 \\
(134 \cdot 8 \text { to } 149 \cdot 1)\end{array}$ & $\begin{array}{r}22 \cdot 3 \pm 1 \cdot 76 \\
(11 \cdot 3 \text { to } 32 \cdot 8)\end{array}$ \\
\hline 30 & 17 & $\begin{array}{c}22 \cdot 3 \pm 0 \cdot 7 \\
(13 \cdot 6 \text { to } 27 \cdot 1)\end{array}$ & $\begin{array}{c}135.5 \pm 1.2 \\
(127.9 \text { to } 144.4)\end{array}$ & About 25 \\
\hline 61 & 10 & $\begin{array}{c}25 \cdot 0 \pm 0.4 \\
(23 \cdot 0 \text { to } 27 \cdot 1)\end{array}$ & $\begin{array}{c}128 \cdot 1 \pm 2 \cdot 2 \\
(115 \cdot 9 \text { to } 138 \cdot 3)\end{array}$ & $\begin{array}{c}127.0 \pm 1.8 \\
(120 \cdot 0 \text { to } 140.9)\end{array}$ \\
\hline
\end{tabular}

Values are expressed as Mean \pm S.E.M. with the range in parentheses.

Table 2. Litter size, length of gestation, and weight at birth in domestic rabbits acting as recipients for the eggs of wild rabbits

\begin{tabular}{ccc}
\hline $\begin{array}{c}\text { Litter } \\
\text { size }\end{array}$ & Time between egg transfer and parturition (days) & Wt of young at birth $(\mathrm{g})$ \\
\hline 1 & $31,31,32,32,32,32,32,33$ & $59 \cdot 0 \pm 1 \cdot 7(52$ to 64$)$ \\
2 & $30,30,31,32$ & $52 \cdot 2 \pm 2 \cdot 7(36$ to 59$)$ \\
3 & $30,30,30,31,31,31,31,33$ & $51.9 \pm 1 \cdot 5(48$ to 61$)$ \\
4 & $30,30,31,31$ & $50 \cdot 5 \pm 1 \cdot 8(41$ to 60$)$ \\
5 & 31,31 & $48 \cdot 9 \pm 1.9(38$ to 57$)$ \\
7 & 30 & $44 \cdot 9 \pm 0 \cdot 6(43$ to 47$)$ \\
\hline
\end{tabular}

Weights are given as Mean \pm S.E.M. with the range in parentheses.

\section{Recipients}

Pregnancy was diagnosed in all except one of the thirty-six recipients about the 10th day following egg transfer and, apart from two in which resorption subsequently occurred, all produced young. In two instances, however, the young were not found-presumably due to cannibalism. The proportions of transferred eggs surviving to term were $49 \%(73 / 148)$ and $38 \%(14 / 37)$ in the recipients for Groups A and B, or 57\% (73/129) and $48 \%$ (14/29), respectively, if recipients with no young are excluded.

In Group-A recipients, the interval from egg transfer to parturition varied from 30 to 33 days, as shown in Table 2, which also includes observations on the birthweights. These were inversely related to litter size, the means varying from $45 \mathrm{~g}$ for litters of seven to $59 \mathrm{~g}$ in litters containing only one young. 
Altogether at least eighty-seven young were produced, including two stillborn; no abnormalities were noted. Apart from four young which died shortly after birth, postnatal survival was excellent.

\section{DISCUSSION}

By combining a series of techniques, including gonadotrophin treatment, artificial insemination with epididymal spermatozoa and egg transfer, it was possible to propagate wild rabbits which would not breed under laboratory conditions. Egg transfer was necessary because pregnancy invariably failed due to failure of the corpora lutea, as in immature gonadotrophin-treated domestic rabbits (Adams, 1953). Considering the poor sexual development of the wild does, the survival to term of almost $50 \%$ of their eggs is most satisfactory, comparing favourably with the results obtained by Chang (1948) and Maurer, Hunt, Van Vleck \& Foote (1968) in domestic rabbits. Moreover, practically all of the recipients maintained pregnancy to term which contrasts with the $30 \%$ (or higher) loss of whole litters in wild rabbits under natural conditions (Brambell, 1944; Poole, 1960) or in cages (Ward, 1971). It appears, therefore, that such heavy mortality is dependent upon factors other than defects within the embryo.

Since wild rabbits may become capable of breeding at 3 months of age (Barrett-Hamilton \& Hinton, 1910-21), it is remarkable that the does born and reared in captivity, although growing well, remained sexually immature; the ovaries $(<50 \mathrm{mg}$ ) and genital tract were still infantile at 7 months of age and 1200 to $1450 \mathrm{~g}$ liveweight, which falls well within the normal weight range for adults (Brambell, 1944). On the other hand, the males became sexually mature and several would copulate if caged and left with oestrous, domestic rabbits, though only one would do so under observation. For the successful reproduction of wild rabbits under laboratory conditions, Ward (1971) considered it necessary to supplement the ration of commercial pellets with fresh vegetation, based on the observations of Poole (1960) relating seasonal breeding activity to the incidence of rain and the growth of new vegetation.

Even after three or four generations of multiplication by artificial means, the majority of the wild rabbits behaved quite differently from tame rabbits kept under similar conditions. The major difference was that the wild rabbits concealed themselves in the straw bedding during the hours of daylight, and became active only during the hours of darkness. Assheton (1910) observed that even after long periods of association with tame rabbits, the wild ones did not show themselves in the daytime. In comparing the behaviour of wild and domestic rabbits in confined populations, Stodart \& Myers (1964) noted that the domestic rabbits stayed above ground whilst resting during the day whereas the wild ones went underground. The fact that wild rabbits do not readily adapt to confined conditions could lead to stress which, in turn, may cause endocrine disturbances affecting reproduction.

The birthweight of the wild rabbit is unknown but it has been suggested on the basis of autopsy material that the average weight is between 40 and $45 \mathrm{~g}$ (Brambell, 1944). This is slightly lower than that recorded in the present study, 
where the weights ranged from 38 to $64 \mathrm{~g}$. The difference can be reconciled, however, on the basis of enhancement attributable to the superior uterine environment provided by the recipients which were $1 \frac{1}{2}$ to 3 times heavier than wild rabbits, relatively small litters coupled with longer gestations, and milk ingested immediately post partum, which may add an average of $2.5 \mathrm{~g}$ to birthweight (C. E. Adams, unpublished observations).

The ovarian response of the wild rabbits to gonadotrophin treatment was very similar to that observed in tame Polish breed rabbits in the same liveweight range (C. E. Adams, unpublished). This result is not unexpected in view of the fact that at equivalent liveweights the natural ovulation rates are also similar, as shown by comparing the observations of Brambell (1944) with those of Adams (1970). This suggests that in the rabbit domestication per se has had little effect on ovulation rate and further reflects a lack of selection for this character, which in any case could only be considered indirectly through litter size.

\section{REFERENGES}

ADAms, G. E. (1953) Studies on growth and reproduction in the female rabbit. Ph.D. thesis, Cambridge University.

ADAMs, G. E. (1958) Egg development in the rabbit: the influence of post-coital ligation of the uterine tube and of ovariectomy. F. Endocr. 16, 283-293.

Adams, C. E. (1962a) Artificial insemination in rodents. In The Semen of Animals and Artificial Insemination Chap. 18, pp. 316-330. Ed. J. P. Maule. Commonwealth Agricultural Bureau, Farnham Royal.

Adams, G. E. (1962b) Studies on prenatal mortality in the rabbit, Oryctolagus cuniculus; the effect of transferring varying numbers of eggs. F. Endocr. 24, 471-490.

ADAms, G. E. (1970) Maintenance of pregnancy relative to the presence of few embryos in the rabbit. F. Endocr. 48, 243-249.

Assheton, R. (1910) Variation and Mendel. Some observations on the crossing of wild rabbits with certain tame breeds. Guy's Hosp. Rep. 64, 313-342.

Barrett-Hamilton, G. E. H. \& Hinton, M. A. G. (1910-21) A History of British Mammals, vol. 2, pp. 176-228. Gurney \& Jackson, London.

Brambell, F. W. R. (1944) The reproduction of the wild rabbit, Oryctolagus cuniculus (L). Proc. zool. Soc. Lond. 114, 1-45.

Chang, M. G. (1948) Probability of normal development after transplantation of fertilized rabbit ova stored at different temperatures. Proc. Soc. exp. Biol. Med. 68, 680-683.

King WiLson, W. (1936) Quoted by Thompson, H. V. \& Worden, A. N. (1956) The Rabbit, p. 83. Collins, London.

Maurer, R. R., Hunt, W. L., Van Vleck, L. D. \& Foote, R. H. (1968) Developmental potential of superovulated rabbit ova. F. Reprod. Fert. 15, 171-175.

Poole, W. E. (1960) Breeding of the wild rabbit, Oryctolagus cuniculus (L), in relation to the environment. C.S.I.R.O. Wildl. Res. 5, 21-43.

STODART, E. \& MYERs, K. (1964) A comparison of behaviour, reproduction and mortality of wild and domestic rabbits in confined populations. C.S.I.R.O. Wildl. Res. 9, 144-159.

WARD, G. P. (1971) Gestation periods and body weights of wild rabbits (Oryctolagus cuniculus) in captivity. $\mathcal{N}$.Z. F. Sci. 14, 10-17. 